\title{
STRENGTHENING THE RURAL WOMEN'S ENTREPRENEURSHIP SPIRIT IN FACING THE ASEAN ECONOMIC COMMUNITY (DA'WAH IN THE ECONOMIC CONTEXT OF SOCIETY)
}

\author{
Sabiruddin b. Juli ${ }^{1}$ \\ E-mail : julisabiruddin@gmail.com \\ Diterima: 06 Desember 2016. Disetujui: 05 April 2017 \\ Dipublikasikan: Mei 2017
}

\begin{abstract}
This article reports the results of a study on how to fill the free market program of ASEAN Economic Community (AEC). Indonesia has significant demographic bonus when compared to other ASEAN countries, so that specifically Indonesia will become an easy target for economic activity (read: free market flow transactions) carried out by all members of ASEAN. Demographic bonus is an opportunity and challenge for the Indonesian people, both for those who live in cities or in the countryside. This condition will be more complicated, if the mapping potential of the population does not become a serious concern for the government and stakeholders so that the people of Indonesia will become the largest consumer for products of ASEAN countries. One of the potential populations of Indonesia is women, because they have specific skills that are able to be directed towards an income. The purpose of this study is to prepare the people of Indonesia who have the skills, especially women in entering the AEC both urban and rural communities. This study uses a qualitative method of observation, interviews and review of documents, such as books, newspapers and others.
\end{abstract}

Keywords: Indonesian Women, AEC, Entrepreneurship

\footnotetext{
${ }^{1}$ Lecturer of subjects Da'wah Studies at the Faculty of Da'wa and Communication Studies IAIN IB Padang. Following postdoctoral Kulliyyah Multimedia and Creativiti, Kolej Universiti Insaniah, Kedah Darul Aman, Malaysia began January 12010 s / d 31 December 2010. Obtaining certificate of Associate Professor.
} 


\section{6 ljtimaiyya: Jurnal Pengembangan Masyarakat Islam 10 (1) (2017)}

\section{Introduction}

The ASEAN Economic Community (AEC), which has been hoping for the past few years, has finally begun in 2016. This reality is likely not only for economic climate change but also potential for influencing social, political, cultural and religious climate change ${ }^{2}$. AEC's presence will be a new episode that characterizes all aspects of ASEAN community, especially in Indonesia ${ }^{3}$.

As one of the member countries of ASEAN, Indonesia has a demographic bonus that is significant, when compared to other ASEAN countries so that specifically Indonesia will become an easy target for economic activity (read: free market flow transactions) carried out by all members of ASEAN. This demographic bonus will be opportunities and challenges for the Indonesian people, both for those who live in cities or in the countryside. AEC provides its own challenges for Indonesia, including the competitiveness of development and innovation, to support financial transactions more efficient, as one source of financing development facilitates international trade, to support the development of the financial sector and to boost economic growth.

This condition will be more complicated, if the mapping potential of the population does not become a serious concern for the government and stakeholders so that the people of Indonesia will be the largest customer for the products of other countries ${ }^{4}$.

One of the potential populations of Indonesia is women, because they have specific skills that are able to be directed towards an income. Women also have a very significant role in the development for the progress of a nation; so far community

${ }^{2}$ Ariawan Gunadi, 'ASEAN Economic Community Impact for Indonesia', Jurnal Opinio Juris, 19 (2014), 2.

${ }^{3}$ Moch. Masykur Afandi, 'Peran Dan Tantangan Asean Economic Community (AEC) Dalam Mewujudkan Integrasi Ekonomi Kawasan Di Asia Tenggara', Spektrum: Jurnal Ilmu Politike Hubungan Internasional, 8.1 (2011), 2.

${ }^{4}$ Pradewi Iedarwati, 'Entrepreneurial Characteristics of Betawi Batik Women Activists', Journal of Entrepreneur and Enterpreneurship, 6.1 (2017), 17-24. 
members who open the small and medium enterprises are women ${ }^{5}$.

Although having many obstacles faced in opening a business, to be sure and optimistic in growing and developing a business that become more creative, innovative, and optimistic is an obligatory. Unfortunately the public space of women is always restrained and improperly constructed, leaving them marginalized or co-opted in society, whereas all their potential must be maximized for the development and progress of Indonesia.

Events such as these are increasingly perceived by the majority of women in the countryside. Therefore, in facing the ASEAN economic community, the role of women as economic actors needs to be strengthened. Therefore strengthening the entrepreneurial spirit of rural women is one of the alternatives to welcome the ASEAN economic community. However, improving the quality of human resources is a specialty, it is important to improve the competitiveness of other countries, if this does not happen then the positive impact of ASEAN's economic society will only be felt by other countries. Therefore, many efforts must be done with the community, especially women. Women have the potential to mobilize people's economy by facing the economic community of ASEAN considering that most of the business actors in Indonesia especially home industry are women.

Women's participation cannot be underestimated, women's toughness in dealing with the crisis in 1998, is one of the tangible evidence recorded in the nation's economic history. Women in life are already accustomed to survive and work to support the family ${ }^{6}$ although the skills are still very limited and in a condition that is not conducive. Along with the development of the age, women labor is slowly shifted by technologies such as machines, skilled labor and restrictions on the types of work are caused by cultural values. It is very unfortunate that in the midst of reality especially women with low economy is the backbone of the family, just as

${ }^{5}$ Nur Achmad and Edy Purwo Saputro, 'Faktor Sukses Wirausaha Wanita', JP Feb Unsoed, 2015, 2.

${ }^{6}$ Nina Aimasari and others, 'Analisis Faktor-Faktor Yang Memotivasi Wanita Untuk Menjadi Wirausaha (Studi Pengusaha Wanita UMKM Di Kota Bandung Tahun 2015)', E-Proceeding of Management, 2.3 (2015), 2795-99. 
men should always be positioned as breadwinners but low wages do not meet the needs of families, so women also have an important role to increase the needs of the family ${ }^{7}$.

Women are the most vulnerable to the effects of economic policy, including ASEAN Economic Community with some policies such as: single market development and labor market liberalization that will ultimately only confront women in dilemmatic situations, including unemployment or cheap labor. Thus their burden will only increase because they have to carry out their domestic role as mothers and household managers and they are required to assume a dual role to be responsible for the family economy.

Seeing all of the potential that exists in Indonesia it must necessarily be optimistic in facing AEC, but it must be balanced efforts to produce products and high-quality workforce, which required improvement of education system, training, or quality management system, innovation and technology.

What must be done is how to create a gender-equitable environment so that women have gaining position in the family, society and country. So that women are more prosperous, not only economically but also politically, socially and culturally. Poverty should be improved and understand the situation of impoverishment so that women's economic independence is no longer limited to discourse and women can really arrange the steps in facing the ASEAN economic community.

\section{Research Methods}

This research uses qualitative method that is: by observation, interview and document review ${ }^{8}$. Qualitative research is a research approach that reveals a particular social situation by describing reality correctly, shaped by words based on relevant techniques and data analysis obtained from natural situations?

\footnotetext{
7 Siti Munfaqiroh, 'Faktor Yang Mempengaruhi Wirausaha Wanita Miskin Untuk Mencapai Keberhasilan Usaha', Jurnal JIBEKA, 10.1 (2016), 58.

${ }^{8} \mathrm{~J}$. Moleong Lexy, Metode Penelitian Kualitatif (Bandung: PT Remaja Rosdakarya, 2014). h. 9

9.Dja'man Satori, Metodologi Penelitian Kualitatif (Bandung: Alfabeta, 2011). h. 25
} 
This study uses descriptive approach that is qualitative, namely: by explaining the phenomenon accurately that researchers find in the field. Further it will be analyzed critically and described in narrative. ${ }^{10}$. Descriptive research is done so that data can be taken in a systematic, actual, and factual; recognize the facts and properties of a particular population to try to describe the phenomenon clearly.

\section{Portraits of the Indonesisan Women Entrepreneurs}

At least, to photograph the gait of entrepreneurs in Indonesia, it cannot be separated in the dynamics of Indonesian employment, in some job advertisements, women always get the top priority of a company or industry that is in need of employees of the company. The tendency of women's election in industry sectors or companies like this sometimes seems to be seductive. However, behind it, all stored a phenomenon that makes amused some circles.

This is exactly the same as the woman initials "AN" which turns out her role as a secretary of a famous private office in Batam only that serves as a mode to enjoy the body of "AN" by his own boss.

The incident above, only a bit sad story experienced by women job seekers, and in fact the incident is triggered by the desire to occupy special or important positions in a company, so that unexpected calamities are often happened. The same cases with this incident are also often felt by most women in Indonesia. So it is not wrong if the Indonesian National Commission of Women states that two out of three women in Indonesia have experienced violence, whether physical violence or sexual violence, and a number of other violences ${ }^{11}$.

While the woman initials "Y" reveals: it is difficult to get a job in accordance with the profession that has been owned, if not in accordance with the experience I have been through, job announcements are not in accordance with the work I have done ${ }^{12}$.

\footnotetext{
${ }^{10}$.J. Moleong Lexy, Metode Penelitian Kualitatif (Bandung: PT Remaja Rosdakarya, 2011). h 3

${ }^{11}$.Interview, AN. 09/10/2015

12. Interview, Y. 12/10/2015
} 
Much different from the incidents above, women who are in the Pesisir Selatan Regency Batang Kapeb District precisely in the Village of Pasar Kuok work as the employees who serve as a pinukuik (Minang pancake) maker, and Lokan satay which is in Ampingterak and Putu in Kambang. This is expressed by several employees working at the place of pinukuik Enggi, one of whom is: the woman initials "WR" revealed, "I work here to increase my husband's income as the head of the family while preserving traditional food of my village as one owned by the Minangkabau community. The demand here is always a lot, therefore the opening hours of the shop is from $07.00 \mathrm{am}$ to $04.00 \mathrm{pm}$ and the food is almost sold out every day ${ }^{13}$.

Similarly, expressed by women with the initials "NU", says that I am a worker here; the goal is to have a job, even though I work only in my own village but I am glad I do what I do in accordance with my nature or situation as an Indonesian woman ${ }^{14}$.

While the woman with the initials "MS" reveals that, I am proud as a woman because it is possible to only work at home for the family, but I work here also for the family, especially to increase the cost of living, because everything is bought expensive.

The number of products produced by Indonesian women is to improve the competitiveness of AEC, especially to improve the products used do not contain harmful ingredients, and to improve the quality and guarantee halalness of the products, this will increase the products of Indonesian women.

Not only that, to improve the work of Indonesian women, they also need side jobs that can direct how to develop their work in order to have the competitiveness of AEC. For that reason, Indonesian women in both rural and urban areas should be given entrepreneurial spirit to always be optimistic in producing the best works.

On the other hand, the Association of Indonesian Women Entrepreneurs (IWAPI) with an employers' organization notes that by 2015 , the number of IWAPI members is 30,000 women spread

13. Interview. WR. 07/10/2015

${ }^{14 . .}$ NU. $10 / 10 / 2015$ 
across the province in Indonesia. Any action of IWAPI can be used as a benchmark of weak entrepreneurship spirit of women in Indonesia. Whereas in 2016, the increasingly competitive competition and the increasing necessities of life makes a man as a creature to open to women, because of limited ability to meet the increasing needs of life.

Thus, Indonesian women should be able to position themselves in accordance with the role that makes family life happy, so the possibilities of cases of violence against women in the family will also be reduced. With the opportunities created for women in Indonesia although only doing a small business, they can keep it to face the AEC.

\section{The Spirit of Entrepreneurship}

The creation of a balanced cooperation in a family, then the entrepreneurial orientation becomes a driving step to improve the economic level in a region. The spirit of entrepreneurship in terms that the author wants to put forward is a form of process activities that can be done by all walks of life, including wives in their families in the form of producing a type of goods that are marketed together. Value spirit of cooperation between husband and wife becomes the principal cause of the harmony within each household.

In addition, women should understand and be aware of their strategic role in fostering their entrepreneurial spirit, without distinction or discrimination. This strategic role is a way or step that can minimize all economic constraints in running or business products together.

From a different point of view, historically it is natural that Muslim women should make Khadija as a reference, she was a trader among Arab women, but she remained faithful to Islamic values. Her nature as a woman turned out not to be a barrier to make buying and selling transactions with the community with other Arab communities. Thus, the value of the spirit of independence in the values of entrepreneurship applied by Khadija was able to influence many traders and they were enthralled with the charm of her policies and wisdoms. 
As a second reference, Khadija was a woman assigned by Umar bin Khatab as a market safety. In short, all visitors and market traders always thrilled their policies and virtues in managing the market. So, it is time for women to come out of the social snare that happens, because in time a man who acts as husband will recognize the greatness and privilege of a wife (woman). In different languages, men's centric ego deprives women of genuine love for creating a better life.

The realization of the above will cause a good number of economists in every family, because of disharmony in a family arising from the cost of living increases and the number of family members that is always increasing. In addition, things that triggers disharmony in the household are including the incompetence between husband and wife in conducting a business. So, here could be an opportunity to give understanding and introduce how to create entrepreneurial spirit to every family, and the importance of cohesiveness in opening a business.

In connection with the above, Allah says in terms of the creation of man both men and women as in the surah of Al-Qur'an (49) verse 13, the meaning: $\mathrm{O}$ mankind, indeed We have created you from male and female and made you peoples and tribes that you may know one another. Indeed, the most noble of you in the sight of Allah is the most righteous of you. Indeed, Allah is Knowing and Acquainted.

The purpose of the above verse, humans are made to be able to live in groups and work with each group. Moreover, the problem is serious enough for women to get out of social concepts that have been constructed by society in general. However, once again the early cooperation between men and women will be able to eliminate the concept that has been built.

Therefore, the orientation of entrepreneurial spirit in this paper is the order to create economic cooperation. Because, togetherness that was created, in the end gives fresh air to men and women.

The base of entrepreneurship is one of the direct manifestations of good values to be one of the causes or prerequisites of a person in order to obtain a good life according to the word of Allah swt in surah (16) verse 97 : 
Meaning: Whoever does righteousness, whether male or female, while he is a believer - We will surely give them their reward [in the Hereafter] according to the best of what they used to do.

It is emphasized in this verse that men and women in Islam get the same reward and that righteous deed must be accompanied by faith. The purpose of the verse above is the dimension of transcendence or faith is an absolute requirement of the happiness of men and women that can be felt. Cooperation established by men and women in managing or managing the economy, must be based on the spirit of the whole godhood, and also the full faith.

In the end, the entrepreneurial spirit, hard work and cooperation based on the whole transcendence dimension will earn rewards or better life opportunities.

\section{Women in the middle of the flow of AEC}

Along with the passage of time and the interchange of time, the substance of time and age that includes women also changes, or at least a shift occurs. Observing and read the conditions of MEA that has started since the beginning of 2016 ago indeed women have a very serious challenge. However, in general the discourse that will be more "sexist" is the discourse about humanism. This discourse will be a parent in the study of the problems of humanitarian cases.

One of the analogies that authors have put forward is related to local products and AEC products. For example, in 2016, Thailand will export its rice throughout Indonesia by sabotaging the price, lowering the price of rice from its marketing destination, such as West Sumatra with its Solok rice. Automatically society will be chasing in buying Thai rice because the price is cheaper.

People's addiction to the rice that they consume often makes people feel dependent on Thai rice. Indirectly local products in West Sumatra will not experience increasing production because of the limitations of consumers who will buy it. Therefore, woman is as the central community to the logistics or daily needs of the family.

Here it takes the participation of women who must be able to maintain local products so as not to be immersed in enjoying the 
results of outsourced products to meet the needs of the family. Due to lack of accuracy in reading the AEC situation will make local products unpopular by community members. Therefore, women also have to have a lot of information about this free market, because it will be bad if they do not understand well, how to deal with current AEC situation.

\section{Concrete Steps}

Discussing women in the contemplation of the world of work, at least can be used as the initial momentum for the rise of women's consciousness collectively to the significance of its role and function in Indonesia's progressive development flows. There are at least three strategic steps in strengthening the role of women in building entrepreneurial spirit for rural women.

\section{The structural steps}

The structural steps referred to in the context of this paper are in the form of strategic and practical efforts undertaken by elements of government and other societies through business spirit of togetherness. Base of spirit of togetherness is used as a basic indicator and the birth of programs that are not only appropriate, timely, but also on target. So the structural formality that is done together will indirectly accommodate all the practical needs of women to a program that is made.

For example, the author wants to offer an integrated program of education development, training, coaching and mentoring to be able to create a product rich in taste, rich in use and even rich in color. This program is not just a program; the local government should be able to meet the target needs of participants about how important the training is, educational program or a number of other activities based on togetherness.

As far as the observations observed in some areas of West Sumatra indicate that there are such activities only serve as "development cakes" so that the main objectives of the activities are not in accordance with the practical needs of women as participants. In the "ridiculous", context, some even make the activity as a complement to the letter of responsibility at the end of the year. 
As a result, the types of education and training activities and various other activities have not reached the level of satisfaction with the proof of lack of women entrepreneurs in Indonesia.

So, the author offers a program that looks different due to the way the program works or the process to produce a cadre of young female entrepreneurs, so that in the end, they will be buds that will change and be able to compete with other ASEAN economic community. In addition to the process and workings of the program, the integration of training materials or programs is more rooted in the practical needs of communities or program participants.

In short, an integrated program will provide the best, according to the participants' basic needs as inspired by one of the verses of the Qur'an surah an-Nahl as mentioned above. The verse contains the nuances of divinity and humanity integrated into one that is human. In this verse the men or women are equally faithful to Allah, and then Allah will give happiness to live in this world and in the hereafter to them both.

The understanding of the concept of drakarin aw unsa (male or female) is clearly evident in generating differentiation values between the status of one's femininity or maleness. Because just with the certainty of doing good deeds with the faith, the happiness or purpose of life to be achieved by someone will be realized. Thus the doctrine or reward (the opportunity to reach the goal of life) becomes a reality.

2. The cultural steps

There are some important notes as a concrete step in strengthening the entrepreneurial spirit of women in welcoming the ASEAN economic community. Cultural concepts are more emphasized on cultural approaches.

The first note is related to the women's self-habituation in trading activities and supported by the theological spirit that the ideals of making life better is a servant's ubudiah obligation to his Lord, Allah azza wajalla.

Thus, participants must make entrepreneurial activity as a tradition, as well as followed by a theological assessment of the habit as a divine spirit. The habituation of entrepreneurial attitudes 
as previously stated will be of special value to the business activities that are being accustomed to it.

Furthermore, these two embedded cultural characters will be able to filter all kinds of cheats that will occur in every business transaction that will be implemented. Meanwhile, those who have instilled the values or theological spirit on the building of culture and traditions that regulate the strong within him/her, it will be the main attraction for foreign traders, so that the business activities that run are seen to receive blessings from Allah swt.

ASEAN economic society that will dominate in the territory of Indonesia must be filed with theological values and culture of habituation (self-culture) so it does not get stuck with doing business by making the status of womanhood as the exploitation of the body individually, because it will give a negative impact on humanity generally.

Such attitudes and events should be avoided so that a healthy business competition can be realized. Especially lately entrepreneurial character owned by women is the attraction to make consumption as a fixed customer which must be as a basic capital that is not owned by most men.

3. Developing a nationwide insight about the free market in the AEC

Each person's actions, policy orientations and life goals and so on are always influenced by one's conceptual insight into something. ASEAN Economic Community becomes a great opportunity and challenge for every member of AEC. The opportunity is open because of the freedom of doing business transactions within the region. The advantage is that women can develop their business transactions within the ASEAN member countries.

Indeed, the issue of the section is the lack of public awareness of Indonesia in establishing the Patent Rights of a business product. For example; the case of rendang of West Sumatra is claimed by Malaysia as the original home-made products of the country. However, since Malaysia as the first country establishes in "proclaiming" and utilizing the rendang products as Malaysian made. However, Malaysians are recognized as rendang makers are 
Indonesian citizens who live in Malaysia or at least come from West Sumatra.

In ASEAN's pre-economic community, the value of rendang OF West Sumatera products has not significantly impacted the products marketed by West Sumatera traders. However, once the AEC is officially echoed, Malaysian parties will automatically charge a Patent Fee for selling the same product as made in Malaysia. Because Indonesian sources have not managed Patent Rights of a business product, then the business people (women entrepreneurs) must be able to see and solve the cases, so that the production of goods does not decrease or even go bankrupt. In addition, the cultural tourism sector in the location areas will also be scattered with the arrival of the AEC.

With the increasing development of tourism sector, rural women can make a culinary that is local wisdom. Thus women not only contribute positively to development, but also have turned into subjects or agents of development.

\section{Interpreting a Job}

Among the many natural traits of human beings, work occupies a high position when carried with the love and sincerity of the soul and even without realizing it that natural nature (work) has been firmly rooted in the personality of every human being. It cannot be denied that the natural nature makes every human being, with full awareness to do something. Just look at when the first human being was born, the beginning of the work done by some of them (babies) are crying, because only cry can be done by a baby in applying his/her submission. In addition, in the later phases it turns out that various things have been done by this human being, without realizing that he/she has done something. With a different language, that every human being has been endowed by the Creator (Allah swt) a natural nature, that is the spirit of work.

Implicitly, the grace is true capable of imprinting and deeprooted within each human being and at the same time accompanied by a deep meaning of every step and motion that he did, without having to put aside the values of work that has been indoctrinated to them since they were born into the world. However, the form of implementation of work values that have 
been obtained cannot be maximally manifest in the daily activities of the man himself.

From here it can be understood that the true meaning of a job in life is one form of consciousness steps that must be done continuously so that as a human being can take the journey from every past step that has been passed through the ages given by Allah swt to someone.

In short, one's self-awareness in interpreting a work that is being run becomes the basic capital in seeing the potential in the future.

The mature consciousness of every human being, in turn, will help him/her to do a job that does give satisfaction to him, not only material satisfaction, but more specifically to the satisfaction of the heart. Therefore, the term interpreted the work in this paper, is deliberately led to form a consciousness of a person that he is a historic man who is able to choose and get a job that matches the level of satisfaction of his heart. So that it will be able to give a value of one's love of what is being felt or cultivated. In other words, starting from the attitude of consciousness in interpreting every job you want to get, it will be able to indirectly give a passion to love a job.

In the present context, precisely, as these values is no longer the calculation for job seekers. This happens because of not only the narrowness of employment but also the dryness of the values of one's independence in forming or creating a job that can bring tranquility in his life. The orientation of life that is supported by a high awareness of the importance of a job in every one's life will ultimately be able to bring various kinds of happiness that cannot be felt or obtained by others. Not to mention, the existence of extrinsic encouragement in the form of high life needs of each human being affects a person to rush in deciding a job that will be done.

Things like this that I often find from various freelance discussions aims to find the truth of reality, between the ideals and reality of job seekers. Most of them are no longer care about the skills and natural abilities they have, and prefer to do a job that is completely beyond their capabilities. As a result, the spirit of testing in getting a job finally becomes a habit and tradition that is almost entrenched in unconscious job seekers. 


\section{The Grief of Job Seekers in the AEC Era}

The spirit of the tests seems unlikely to have a significant chance of finding or getting job in the era of the ASEAN Economic Community (AEC). This condition makes job seekers will enjoy unemployment activities that lead to negative attitudes toward the environment and society. Even the climax of the act will give them a great chance to act as a hit man. It is understood that the culture of "Aseanic" will be globalized into the whole culture of society in the ASEAN country. This culture will later shape and influence job seekers to find other options in work. That choice will be a process to increase the high crime cases in the region.

The described conditions illustrate the form of employee obsessions. Grief finally becomes a term that will sound familiar, when describing this condition. If it is like that, every human being, especially Indonesia people need to really prepare the whole aspects of life to face the AEC free market, so they can be free from wild choices in the work. In addition, strengthening the values of self-reliance and local culture becomes a necessity so that these values are not buried by foreign cultures who visit all regions in Indonesia. Furthermore, the government and all stakeholders need to keep together, especially in preparing jobs for future generations.

In preparing the work for that generation, it requires a concerted effort, to make the work as a duty and trust from God, or proof of submission to Him will affect one's attitude in doing the best work to be abandoned. Yet in the context of Islam, such works show a concept of attitude or deed with the value of absanu amala (QS, 67:2). The concept of absanu amala, whose deeds are the best, becomes an important inspiration to every human being in order to always correct the deficiencies so that his good can reach the realm of perfection. Moreover, as a previous generation, it should manifest this verse in the sense of abandoning quality works for future generations. At least the message of surah an-Nisa 'verse 9 as below can be used as a source of encouragement value for the best job, 
190 Ijtimaiyya: Jurnal Pengembangan Masyarakat Islam 10 (1) (2017)

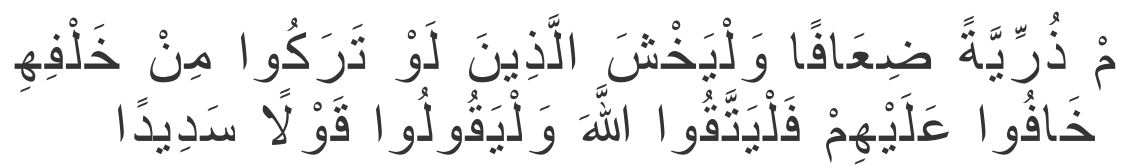

Meaning: And let those [executors and guardians] fear [injustice] as if they [themselves] had left weak offspring behind and feared for them. So let them fear Allah and speak words of appropriate justice.

In other words, the AEC's grief can only be denied by reinforcing the values of consciousness, both emotional and spiritual awareness of a number of other consciousness that can raise the passion and love of oneself to do a job as well as possible.

The awareness that has been nurtured must always be maintained the integrity of divine values that have been embedded in a person so that it can be a light in the darkness of life around $\mathrm{him} / \mathrm{her}$. The reason, climate change changes in various areas of life in the advent of the AEC free market in the future in addition to be a challenge for the community and become an opportunity to manifest self-servitude to Allah swt. The manifestation of submission and servitude will give significance to each individual in his or her drift of divine values. At the end, in the context of such an atmosphere, the people who want the brightness of the soul will also increase, along with the economic improvement in a developing region. Thus, the presence of AEC should be a serious concern to job seekers as they are easy targets to be used as a sacrifice of the times, so that job seekers' obstacles will continue. Therefore, before the time comes to the job seekers in order to raise awareness of everything that supports the positive development of life, whetheher it is awareness, strong religious motivation or a number of other drivers (Daya, 22004:xi).

\section{Cultivating the Spirit of Loving Work}

This cultivating term goes further with an understanding of the problem of getting used to loving a work continuously and a structure that will ultimately not form a tradition within the frame of culture. In short, cultivating means making it something to 
become a culture of its own ${ }^{15}$. In the culture to be formed there is always a central culture that will serve as a starting point in the formation of culture itself. With such a complex problem, it is almost impossible to find strategic alternatives, in such a fast time, to cultivate the values that the author intends. Because in the process of cultivating always requires a relatively long period, and it will involve the process of planting value or internalization of the values of love of the work itself.

Although it takes a long time in the process of civilization, at least in the context of this paper, there are at least two opportunities that can be utilized in civilizing itself.

1). Through Habituation at Work

Habituation at work is interpreted not only as a full presence in following a job, but also in the concept of habituation, it is true that there is a value that is developed and developing in each human. Naturally we have understood that since we were born also the nature of work has been given by Allah to almost all human beings. This natural nature serves as the prime mover or the basis for loving the whole series of work done.

Furthermore, this natural nature, on the different side always wants something meaningful to be happy in enjoying his job. Nasaruddin Umar in the book The Doors to Happiness (Pintupintu Menuju Kebabagiaan) explains that in achieving happiness in the career, there is no movement without spirit, because that spirit is the idea of every action and step of every work to be accomplished. At least the phrase expressed by Nasaruddin Umar can be reflected that in the birth of a cultural attitude, the spirit or values or sincerity is the most fundamental aspect to civilize a job so that work is not as a burden, but as something meaningful to one's life and the surrounding community.

The concept of habituation at work is a cultural process that has different nuances in achieving the desired effect. The process of influencing also tends to be caused by several important factors, such as social environment, belief systems and a number of other

15 Kuntowijoyo, Paradigma Islam: Interpretasi Untuk Aksi (Bandung: Mizan, 2010).hal.511 


\section{Ijtimaiyya: Jurnal Pengembangan Masyarakat Islam 10 (1) (2017)}

factors. Therefore, culturally in cultivating the spirit of loving the work, each aspect will give its own influence. Sometimes, the influence of social environment is more dominating, but on the other hand the influence of the belief system dominates all. From the perspective of Islam, at least the Qur'an has informed its people, such as habituation at work, for example addressed through the attitude of consistency and istiqamah towards a job. As stated in the following surah al-Inshirah:

The meaning: So when you have finished (with your immediate task), still strive hard, (then toil), And to your Lord turn (all) your attention.

It means that that some interpreters interpret if you (Muhammad) have finished preaching then worship Allah; when you have finished doing the world's business to do the business of hereafter, and there is more to say: when you have finished performing prayer and then pray to Allah. According to the Ministry of Religious Affairs's interpretation, the above verse instructs indirectly, in order to utilize time as effectively as possible, so that there is no wasted time in running activities.

The work that has finished must be stopped when it is completely finished, after that a new job can be started. This interpretation, if reflected on a job, will have the opportunity to make the high quality result and productivity that can be clearly measured. In other words, time is always a valued friend of the real workers. Moreover, they will also be able to maximize their work time with their work productivity.

If viewed in the perspective of the development of free market which includes the AEC region, the spirit or value of the teachings of the Qur'an will be able to break the rate of economic growth either individually or collectively. Time management as the solution given by Islam has a significant impact on the progress of development of a nation. This is because the effectiveness of time which is managed and regulated by a company or an individual will produce a useful work product. Moreover, it is accompanied by a spirit of consistency of work in which means that if an employee has completed a job, then he must complete a different job. This implies that the conception of the value offered by Islam in the 
context of this work has greater meaning and significance for the benefit of a company or individual.

On the different side, Islam not only puts work as an orientation material that will become a servant of material deity, but Islam is more emphasis on the inner satisfaction in running a job. This is a piece of the concept of value that needs to be accustomed to cultivate the spirit of loving the work itself.

\section{2). Increasing the Awareness of Theological Work}

That most ASEAN economic societies in implementing the AEC free market, will be ensnared in an economic capitalism using every means to gain profit. This is very different from the moral message of Qur'an to the Islamic community. For example, Islam teaches that every sale and purchase transactions carried out, done on the basis of likes (not because of compulsion). In addition, in terms of weighing Islam also teaches that merchants do not apply cheating to the scales, because the act does not bring benefits to both parties, even buying and selling done in such a way, will only kill humans before the human being killed, therefore Allah Almighty puts merchants as one of His servants who get the shade of Allah SWT in heaven later.

Two examples of attitudes and deeds are manifestations of submission and obedience to the creator, Allah Almighty. However, very few of the Muslims apply such attitudes and characters; they are only those who have a relatively high level of awareness in making religion as a spirit in all the dynamics of life they run. In the upcoming era of ASEAN economic society (AEC), people who are able to increase their theological awareness successfully can cultivate the spirit of loving that work.

As a servant of God, the theological consciousness is the embodiment of divine values applied by a person, whoever it is, to encourage his passion for loving work. It means that the Islamic society always makes a passion as one of their love to God. The magnitude of the impacts and effects of the AEC free market has been measurably clear, good or bad, so much as the challenge of the "Aseanic" currents that emerge leaving a complex and multicomplex problem and requires a number of settlement measures.

The most fundamental for society is the need for a job as well as productivity of the work result of a lot of loss, thus causing labor 


\section{Ijtimaiyya: Jurnal Pengembangan Masyarakat Islam 10 (1) (2017)}

violence in the progress of nation-building. Thus, in the context of such situations and conditions, it is natural that Indonesian Islamic society embodies the value and spirit of loving work so as to build a "new" culture oriented to the productivity of the work. Once again, Islamic teachings of Islam is the main spirit that became pillars for the Islamic community in the economic trade period in the era of ASEAN economic society (AEC) which has started since early 2016.

\section{Conclusion}

Despite the inherent social construction that women are weak creatures, who are only able to serve in domestic territories, such as wells, kitchens, and mattresses, seem to be pushed as far away from the lives of men and women. AEC is present in 2016, forcing the entire ASEAN family to work together to meet the increasing needs of life. So only the harmony of men and women can bring happiness to each of those who are lived through the entrepreneurial spirit of rural women so that cooperation and harmony relations can be realized and no more must be used as a scapegoat.

\section{References}

Achmad, Nur, and Edy Purwo Saputro, 'Faktor Sukses Wirausaha Wanita', JP Feb Unsoed, 2015, 2

Afandi, Moch. Masykur, 'Peran Dan Tantangan Asean Economic Community (AEC) Dalam Mewujudkan Integrasi Ekonomi Kawasan Di Asia Tenggara', Spektrum: Jurnal Ilmu Politik. Hubungan Internasional, 8 (2011), 2

Aimasari, Nina, Astri Ghina, Universitas Telkom, Woman Entrepreneur, and Factor Analysis, 'Analisis Faktor-Faktor Yang Memotivasi Wanita Untuk Menjadi Wirausaha (Studi Pengusaha Wanita UMKM Di Kota Bandung Tahun 2015)', E-Proceeding of Management, 2 (2015), 2795-99

Al-Qur'an Al-Karim

Gunadi, Ariawan, 'ASEAN Economic Community Impact for 
195 Ijtimaiyya: Jurnal Pengembangan Masyarakat Islam 10 (1) (2017)

Indonesia', Jurnal Opinio Juris, 19 (2014), 2

Iedarwati, Pradewi, 'Entrepreneurial Characteristics of Betawi

Batik Women Activists', Journal of Entrepreneur and Enterpreneurship, 6 (2017), 17-24

Kuntowijoyo, Paradigma Islam: Interpretasi Untuk Aksi (Bandung: Mizan, 2010)

Lexy, J. Moleong, Metode Penelitian Kualitatif (Bandung: PT Remaja Rosdakarya, 2014)

-, Metode Penelitian Kualitatif (Bandung: PT Remaja Rosdakarya, 2011)

Munfaqiroh, Siti, 'Faktor Yang Mempengaruhi Wirausaha Wanita Miskin Untuk Mencapai Keberhasilan Usaha', Jurnal JIBEKA, 10 (2016), 58

Satori, Dja'man, Metodologi Penelitian Kualitatif (Bandung: Alfabeta, 2011) 